\title{
Impact of moderate drought and shading on morphological traits of Quercus suber L. and Quercus canariensis Willd seedlings
}

\author{
Taher Mechergui ${ }^{1}$, Marta Pardos $^{2}$ \\ ${ }^{1}$ Faculté des Sciences de Bizerte (FSB), Jarzouna - 7021. Tunisie. \\ ${ }^{2}$ Instituto Nacional de Investigacion y Tecnologia Agraria y Alimentaria (INIA). Centro de \\ Investigacion Forestal. Ctra. de La Coruña, Km. 7,5. 28040 Madrid-Spain.
}

\begin{abstract}
The main objective of this study was to investigate the effect of shading and water availability on tree seedling growth of cork oak (Quercus suber L.) and zeen oak (Quercus canariensis Willd). To reach this objective, two light intensities (moderate $(L+)$ versus low $(L-)$ intensity) and two water regimes (well-watered $(W+)$ versus moderate drought $(W-))$ were applied. Cork oak seedlings growing under well-watered conditions were able to increase their height in response to low light intensity, while those growing under water deficit were not. By contrast, zeen oak's response to light was independent of water regime with greater height under $L$ - than under L+. Diameter growth was lower under $L$ - than under $L+$ for cork oak, and similar under both light intensities for zeen oak. Balance between height and diameter was adversely affected under L-for both oaks, while that between shoot and root biomass was adversely affected only for cork oak, compared to L+. The effect of water stress resulted in a reduction in diameter growth, root biomass, and total biomass and an increase in shoot-to-root ratio for zeen oak. Our results suggest that low water availability may be the bottleneck for recruitment of cork oak seedlings in shaded habitats.
\end{abstract}

Keywords: cork oak, drought, light, regeneration bottleneck, zeen oak

\section{Introduction}

Light and water are the main factors that determine plants' growth and distribution [1]. Both factors may act in a non-coordinate manner rendering a segregation in species regeneration niches $[2,3]$. Light is an energy source for plants. It acts at least on three processes: the photosynthesis of the assimilates by the leaves, the elongation of the stem (photomorphogenesis) [4] and the development of the root system which will be affected in the first place by a decrease on photosynthesis [5]. Certain plants are more or less demanding in light. The difference in light consumption between light-demanding species and shade-tolerant species is between 50 to 100 times [6]. A lack of light involves a reduction of stem diameter [7] and an increase in the shoot elongation [8], chlorophyll content [9], leaf area [8, 10, 11], surface mass [8], length of the petioles [10, $11]$ and internodes $[10,11]$. Under low light, first-year oak seedlings usually produce only one growth unit $[12,13]$, which is determined by stored reserves in the acorns. Once the reserves are depleted, survival and growth of oak seedlings are dependent on photosynthates produced by new leaves [14]. Acclimation to different light environments occurs on the whole-plant scale as well as on the leaf scale [15]; leaf acclimation could be morphological, anatomical or physiological [16].

Water is everywhere the paramount factor ( 85 to $90 \%$ ) of the total fresh weight of the plants. It conditions the forest production both for its qualitative (spatial distribution of the species) and quantitative effect on the growth [6]. The effects of water stress are numerous and vary according to the genotype, the developmental stage of the plant and the severity and the duration of the stress [17]. The water stress appears in two forms, the lack of water and its excess. In this study we were interested only in the lack of water. At the level of the tree, a water deficit can affect the components of its two parts, aerial and underground. Thus, water stress reduces the diameter and height growth, weakens the capacity of trees to withstand the other stresses of the environment, affects the allocation of the assimilates and influences other development processes, namely flowering, fructification and reproduction [17]. At the forest population level, water stress increases mortality and can result in the replacement of the existing species by more resistant ones. It also reduces the leaf area [17] which leads to a reduction of foliar transpiration, by increasing the resistance of stomata, but also to a reduction of the available assimilates [18] by reducing the photosynthetic activity. Zahner [19] reported also a high sensitivity of the shoot growth to a water restriction. In addition, the annual increment can be reduced if one of the growth units underwent a water deficit during its development [20]. A water restriction can be also responsible for the premature senescence of leaves and sometimes their fall [20]. Nevertheless, under difficult conditions, characterized mainly by a water deficit, this premature fall of leaves can constitute a strategy of resistance of plants to water stress enabling them to reduce the losses of water and to prolong their lifetime [21]. With regard to the underground part, a high degree of sensitivity was proven for oaks under a water restriction 
$[22,23]$. In an experiment with three oak species (Quercus suber, $Q$. canariensis and $Q$. coccifera), Ksontini [24] observed that water stress resulted in a reduction in root development.

For the experiment, we used saplings of two Mediterranean oak species, the semi-deciduous zeen oak (Quercus canariensis Willd.) and the evergreen sclerophyllous cork oak (Quercus suber L.). Zeen oak is a shade-tolerant species [25] that grows usually at moderate altitudes (700-1100 m) [26], under 1000 to $1150 \mathrm{~mm}$ of precipitation and on deep soils [27]. Cork oak grows at lower altitudes $(<700 \mathrm{~m})$ [26], under 650 to $980 \mathrm{~mm}$ of precipitation and on shallow soils [25]. It is usually exposed to more severe drought during the summer [27], being a typical sclerophyllous species, with lower tolerance than zeen oak to shade [25]. In Tunisia, both cork oak and zeen oak are mainly located in the northwest region, the most humid area of the country, occupying an area of 70113 and 8332 ha, respectively [28]. Both species have a high ecological, social and economic value. However, nowadays, the Tunisian cork oak and zeen oak forests suffer from very low regeneration success [8] because of the high seed predation, the inability of young plants to successfully compete for light and soil resources [4], and the high early seedling mortality rate usually due to water stress. In this study we focused light and water stress factors. Both factors may be considered as the main climatic limiting factors that control regeneration success of forest tree species in the Mediterranean forests [29]. Experiments examining the effect of water stress and shade are often carried out separately. In addition, studies investigating the growth response of oak seedlings to either water stress or shade were often limited to height, diameter and biomass measurements [30, 31, 32, 33]. However, like other oak species [34, 35], zeen oak [36] and cork oak [37] have a typically rhythmic pattern of height growth. The study of the periodic height growth pattern of oak species allows the main stem to be divided on other morphological entities called the growth unit (GU) and gives useful information on this growth response characterization. The experiment was set up to ascertain 1) the effect of water stress and/or light intensity on the morphological traits of containerised cork oak and zeen oak seedlings and 2) to determine if water stress decreases seedlings' acclimation to shade. We tested the following hypotheses: (1) shade and water stress will affect seedling growth in a different way depending on the trait considered, and (2) water stress may overrule the morphological acclimation to shade.

\subsection{Plant material and experimental design}

\section{Materials and methods}

The experiment was arranged as a factorial design with two watering regimes (well-watered versus moderate stress) and two light levels (moderate versus low light intensity). Two oak species, cork oak (Quercus suber L.) and zeen oak (Quercus canariensis) were used for this experiment. Acorns were harvested from trees at Oued elballoutin in Northwestern Tunisia (36 44'57.53'” N, 8 ${ }^{\circ} 54^{\prime} 33.57^{\prime \prime} \mathrm{E}$, elevation $200 \mathrm{~m}$ a.s.1.). The study was carried out in a greenhouse at INIA (Madrid-Spain, $\left(40^{\circ} 27^{\prime} 20^{\prime \prime} \mathrm{N}, 3^{\circ} 44^{\prime} 58^{\prime \prime} \mathrm{W}, 595 \mathrm{~m}\right.$ a.s.l.)).

Collected acorns were kept in moist plastic bags at $4{ }^{\circ} \mathrm{C}$ until germination in December 2009. One germinated acorn was planted in each 3-L pot (truncated square pyramid containers, $25 \mathrm{~cm}$ height, $169 \mathrm{~cm}^{2}$ and $64 \mathrm{~cm}^{2}$, upper and lower cross-sectional area, respectively), filled with a mixture of peat moss (KEKKILA $50 / 50)$ and vermiculite $(1: 3, \mathrm{v} / \mathrm{v})$. Sixty four acorns by species were sown. Pots were kept well watered three days per week (15 min) inside a greenhouse until mid-March 2010. On 15 March 2010, seedlings were randomly divided in two groups according to the water regime, one group was watered to field capacity three days (15-20 min) per week $(\mathrm{W}+)$, while the other group ( $\mathrm{W}-)$ was watered one day per week (15-20 min). Volumetric soil water content in the well-watered seedlings (W+) was maintained at field capacity, while seedlings subjected to moderate stress ( $\mathrm{W}-$-) were allowed to dry to a water content at $60 \%$ of field capacity. The exact amount of water supplied in the $\mathrm{W}$ - treatment was a function of the volume of water lost under the low photosynthetic photon flux density (PFD), which had the minimum evaporative demands. By this means, a slow rate of imposition of the water stress conditions was assured.

Seedlings under each water regime were randomly divided in two groups according to the two light environments, one of which was grown under metal frames $(50 \times 80 \times 150 \mathrm{~cm})$ with different layers of neutral shade white cloth (Polysack Plastic Industries Ltd., Israel) to produce the two light environments. The design of the frame was optimized to avoid any effect on the temperature of the air in contact with the plants. The average PFD inside and outside metal frames was $200 \mu \mathrm{mol} \cdot \mathrm{m}^{-2} \cdot \mathrm{s}^{-1}$ and $90 \mu \mathrm{mol} \cdot \mathrm{m}^{-2} \cdot \mathrm{s}^{-1}$, respectively. They correspond to moderate (L+) and low (L-) light intensities, respectively. Sixteen plants from each species were grown under each combination, which makes a total of 64 plants by species.

\subsection{Growth measurements}

Measurements were made on all seedlings of each species at the end of the experiment (December 2010). Measured parameters for each species at the whole-plant were basal diameter, height growth, height-to-diameter ratio and biomass of the different fractions. The weight of the above- and below-ground biomass was measured after drying at $60^{\circ} \mathrm{C}$ for one week. Total biomass was obtained by making the sum between the above- and below-ground biomass. 
Oak height growth occurs in a rhythmic pattern with periods of uninterrupted terminal bud growth (flushes) alternating with periods of bud development and apparent rest [35]. During each growth flush, a distinct portion of the stem called the GU is established. Thus, the measured parameters at the stem level, at the end of the growing season, were the number of flushes established by the main stem and length of the GU for each flush.

\subsection{Statistical analysis}

Quantitative variables such as height growth, basal diameter, height-to-diameter ratio, GU length, biomass, and shoot-to-root ratio were subjected to a two-way ANOVA (water regime and light intensity), using the PROC GLM procedure. For each analysis, when the ANOVA was significant, statistically significant differences between means were identified using Tukey test.

Qualitative variable (number of GU established on the main stem) was expressed in percentage (\%). A comparison of mean percentages was then performed using a $\chi^{2}$-test with the PROC FREQ procedure. Differences, between means or proportions, were considered significant at $\mathrm{P} \leq 0.05$.

All statistical analyses were performed using SAS program, version 9.2.

\subsection{Height}

\section{Results}

Height growth was significantly impacted by water regime, light intensity, and their interaction in cork oak, but by light intensity in zeen oak (Table I). Zeen oak's height growth was, on average, greater under low than under moderate light intensity (Fig. 1A). This trend was also observed in well-watered cork oak seedlings (Fig. 1B), while height growth in water stressed cork oak seedlings was similar under both light intensities.

Table I. Analysis of variance for height growth in cork oak and zeen oak seedlings. Factors are light, water, and their interaction.

\begin{tabular}{|l|l|c|c|}
\hline Variable & Factors & Cork oak & Zeen oak \\
\hline \multirow{4}{*}{ Height } & Water & $0.0327^{*}$ & 0.2052 \\
\cline { 2 - 4 } & Light & $0.0021^{*}$ & $<0.0001^{*}$ \\
\cline { 2 - 4 } & Water $\times$ light & $0.0311^{*}$ & 0.2564 \\
\hline
\end{tabular}

Asterisk (*) shows significant differences between treatments at $P \leq 0.05$ (ANOVA, Tukey test).

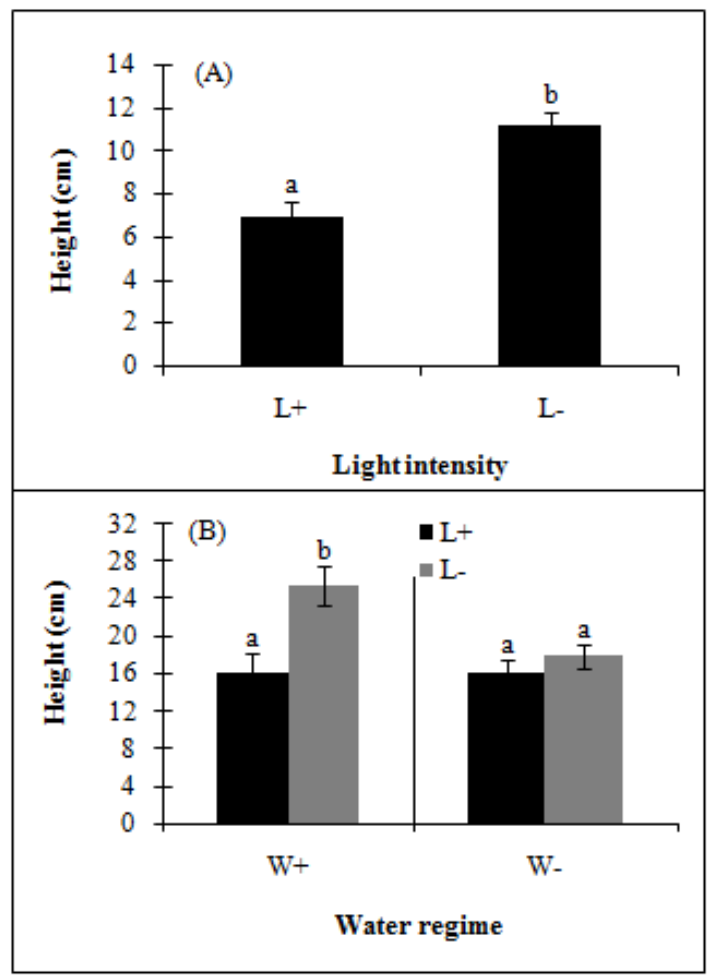

figure 1. Height growth according to light intensity (moderate (L+) versus low (L-) light intensity) for zeen oak $(\mathrm{A})$, and water regime (well-watered $(\mathrm{W}+)$ versus moderate stress $(\mathrm{W}-)$ ) and light intensity (moderate $(\mathrm{L}+)$ versus low (L-) light intensity) for cork oak (B). Means \pm standard error (SE). Letters show in (A) significant differences between light levels, and in (B) light levels within each water treatment. 


\subsection{Basal diameter and height-to-diameter (H/D) ratio}

Basal diameter growth was significantly influenced by light intensity for cork oak, and by water regime for zeen oak; the interaction between water regime and light was not significant in either species (Table II). Average basal diameter was greater for well-watered than for water stressed seedlings $(4.8 \pm 0.1$ vs. $4.1 \pm 0.1$ $\mathrm{mm})$. Contrary to height growth, average basal diameter was greater under moderate than under low light intensity $(3.9 \pm 0.09$ vs. $3.3 \pm 0.1 \mathrm{~mm})$. Height-to-diameter ratio was significantly different between light intensities for both cork oak and zeen oak (Table II). It was, on average, higher under low than under moderate light intensity for both oaks (Fig. 2).

Table II. Analysis of variance for basal diameter and height-to-diameter ratio in cork oak and zeen oak seedlings. Factors are light, water, and their interaction.

\begin{tabular}{|l|l|c|c|}
\hline Variable & Factors & Cork oak & Zeen oak \\
\hline \multirow{4}{*}{ Diameter } & Water & 0.0775 & $0.0075^{*}$ \\
\cline { 2 - 4 } & Light & $0.0001^{*}$ & 0.0699 \\
\cline { 2 - 4 } & Water $\times$ Light & 0.9651 & 0.0564 \\
\hline \multirow{2}{*}{$\begin{array}{l}\text { Height-to-diameter } \\
\text { ratio }\end{array}$} & Water & 0.1265 & 0.9485 \\
\cline { 2 - 4 } & Light & $<0.0001^{*}$ & $<0.0001^{*}$ \\
\cline { 2 - 4 } & Water $\times$ Light & 0.1384 & 0.6793 \\
\hline
\end{tabular}

Asterisk (*) shows significant differences between treatments at $P \leq 0.05$ (ANOVA, Tukey test).

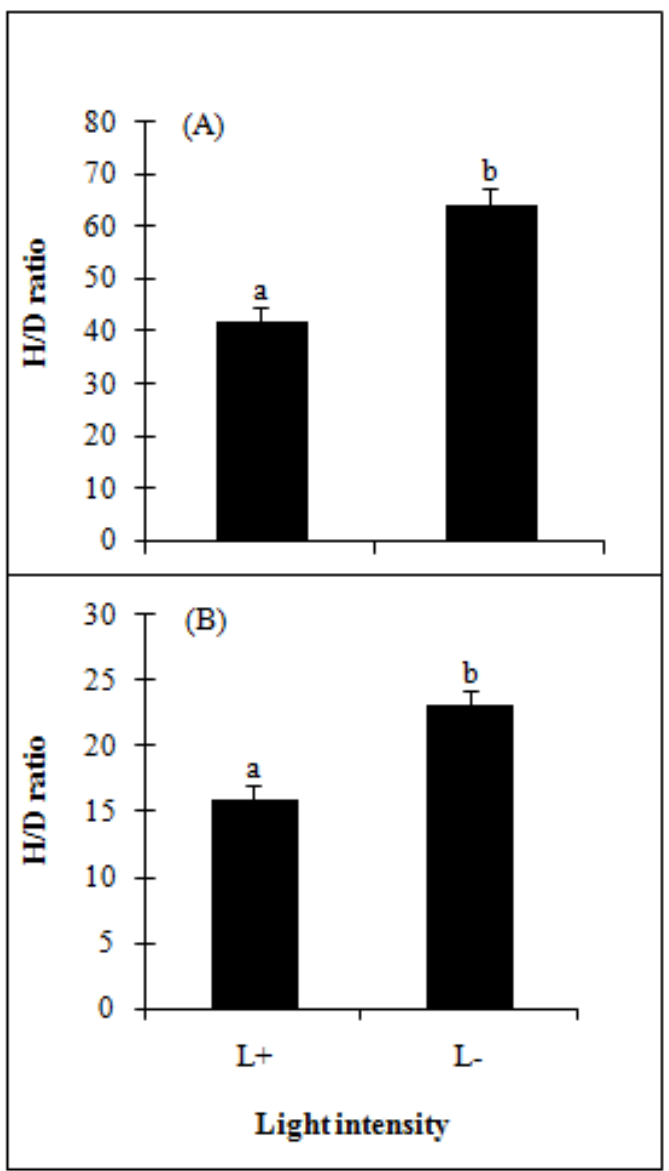

figure 2. Height-to-diameter ratio on cork oak (A) and zeen oak (B) seedlings according to light intensity (moderate $(\mathrm{L}+)$ versus low (L-) light intensity). Means \pm SE. Letters show significant differences between light levels.

\subsection{GU Length}

The decomposition of the main stem in GU showed that seedlings established during all the growing season 1 to $2 \mathrm{GU}$. This trend was observed for both species. Both the first and the second GU were significantly affected by light intensity in cork oak (Table III). However, only the first GU was significantly affected by light intensity in zeen oak. Water regime and its interaction with light intensity had no significant effect neither for the first GU nor for the second GU, for both oaks. For both species, GU was, on average, longer under low than moderate light intensity (Fig. 3). 
Table III. Analysis of variance for growth unit (GU) in cork oak and zeen oak seedlings. Factors are light, water, and their interaction.

\begin{tabular}{|l|l|c|c|}
\hline Variable & Factors & Cork oak & Zeen oak \\
\hline \multirow{3}{*}{ First GU } & Water & 0.2070 & 0.7875 \\
\cline { 2 - 4 } & Light & $0.0083^{*}$ & $0.0064^{*}$ \\
\cline { 2 - 4 } & Water $\times$ Light & 0.4034 & 0.3015 \\
\hline \multirow{3}{*}{ Second GU } & Water & 0.7492 & 0.8065 \\
\cline { 2 - 4 } & Light & $0.0057^{*}$ & 0.0594 \\
\cline { 2 - 4 } & Water $\times$ Light & 0.1409 & 0.0875 \\
\hline
\end{tabular}

Asterisk (*) shows significant differences between treatments at $P \leq 0.05$ (ANOVA, Tukey test).

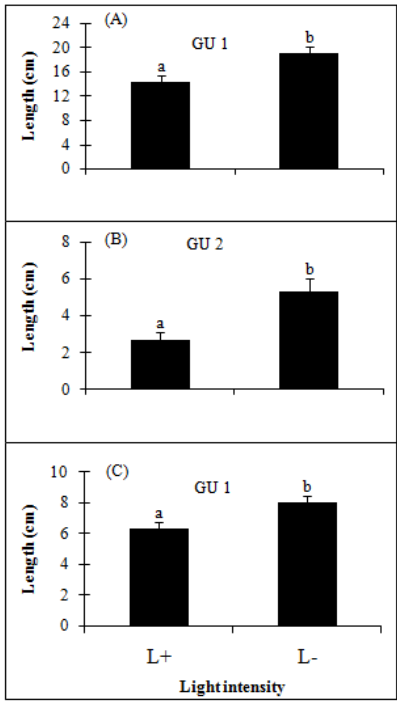

figure 3. Growth unit (GU) length of the first (GU1) and the second (GU2) GU on cork oak seedlings (A, B), and of the first GU on zeen oak seedlings (C) according to light intensity (moderate (L+) versus low (L-) light intensity). Means \pm SE. Letters show significant differences between light levels.

\subsection{Number of GU}

The number of GU was not dependent neither on water regime $(P=0.1049)$ nor on light intensity $(\mathrm{P}=0.1913)$ for zeen oak. For cork oak, this number was significantly dependent on light intensity $(\mathrm{P}=0.0178)$, but independent of water regime $(\mathrm{P}=0.7639)$. There was no significant difference in the percentage of plants having established $1 \mathrm{GU}$ under both light intensities (Fig. 4). By contrast, there was a significant difference in the percentage of plants having established $2 \mathrm{GU}$, with a lower value under low than under moderate light intensity.

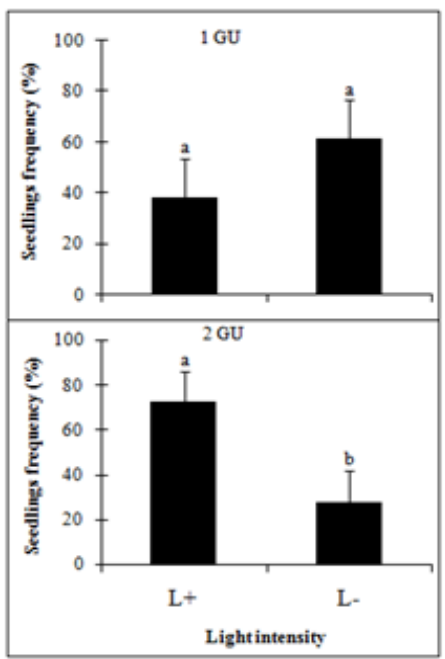

figure 4. Frequency of cork oak seedlings (\%) with one (1 GU) and two (2 GU) growth unit (GU) according to light intensity (moderate $(\mathrm{L}+)$ versus low $(\mathrm{L}-)$ light intensity). Seedling percentage \pm likelihood confidence limits, at $5 \%$ threshold. Letters show significant differences between light levels. 


\subsection{Biomass growth and shoot-to-root ratio}

Neither water availability nor light had a significant effect on above-ground biomass for both oak species (Table IV). However, both underground biomass and total biomass were significantly affected by light intensity for cork oak, and by water regime for zeen oak.

For water regime, both underground biomass and total biomass were, on average, greater for well-watered than water stressed seedlings (Fig. 5). For light intensity, average underground biomass and total biomass was lower under low than under moderate light intensity (Fig. 5).

The shoot-to-root ratio was significantly affected by light intensity in cork oak, and by water regime and light intensity in zeen oak (Table IV). For water regime, the shoot-to-root ratio was, on average, lower for well-watered than for water stressed seedlings $(0.132 \pm 0.008$ vs. $0.159 \pm 0.009)$. For light intensity, this ratio was, on average, higher under low than under moderate light intensity for both species (Fig. 6).

Table IV. Analysis of variance for above-ground biomass, underground biomass, total biomass and shoot-to-root ratio in cork oak and zeen oak seedlings. Factors are light, water, and their interaction.

\begin{tabular}{|l|l|c|c|}
\hline Variable & Factors & Cork oak & Zeen oak \\
\hline Above-ground biomass & Water & 0.1189 & 0.1076 \\
\cline { 2 - 4 } & Light & 0.7724 & 0.0662 \\
\cline { 2 - 4 } & Water $\times$ Light & 0.4100 & 0.1629 \\
\hline \multirow{3}{*}{ Underground biomass } & Water & 0.1426 & $0.0068^{*}$ \\
\cline { 2 - 4 } & Light & $<0.0001^{*}$ & 0.8055 \\
\cline { 2 - 4 } & Water $\times$ Light & 0.4999 & 0.1236 \\
\hline \multirow{3}{*}{ Total biomass } & Water & 0.1180 & $0.0103^{*}$ \\
\cline { 2 - 4 } & Light & $<0.0001^{*}$ & 0.6127 \\
\cline { 2 - 4 } & Water $\times$ Light & 0.4649 & 0.1314 \\
\hline Shoot-to-root ratio & Water & 0.6997 & $0.0414^{*}$ \\
\cline { 2 - 4 } & Light & $0.0177^{*}$ & $<0.0001^{*}$ \\
\cline { 2 - 4 } & Water $\times$ Light & 0.5139 & 0.1191 \\
\hline
\end{tabular}

Asterisk (*) shows significant differences between treatments at $P \leq 0.05$ (ANOVA, Tukey test).

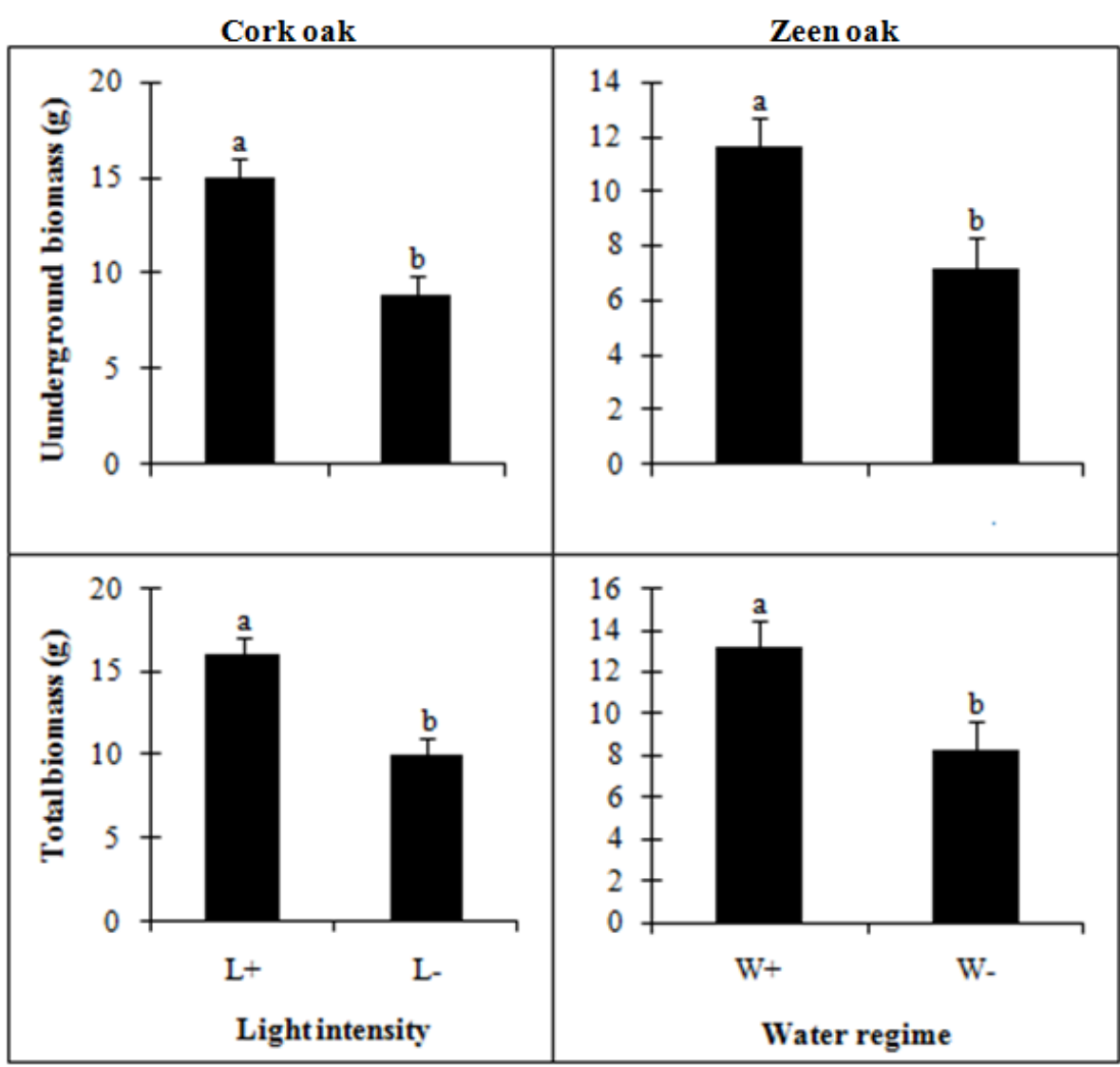

figure 5. Underground biomass and total biomass according to light intensity (moderate (L+) versus low (L-) light intensity) for cork oak (left) and water regime (well-watered $(\mathrm{W}+)$ versus moderate stress $(\mathrm{W}-)$ ) for zeen oak (right). Means \pm SE. Letters show significant differences between light levels (left) and between water regimes (right). 


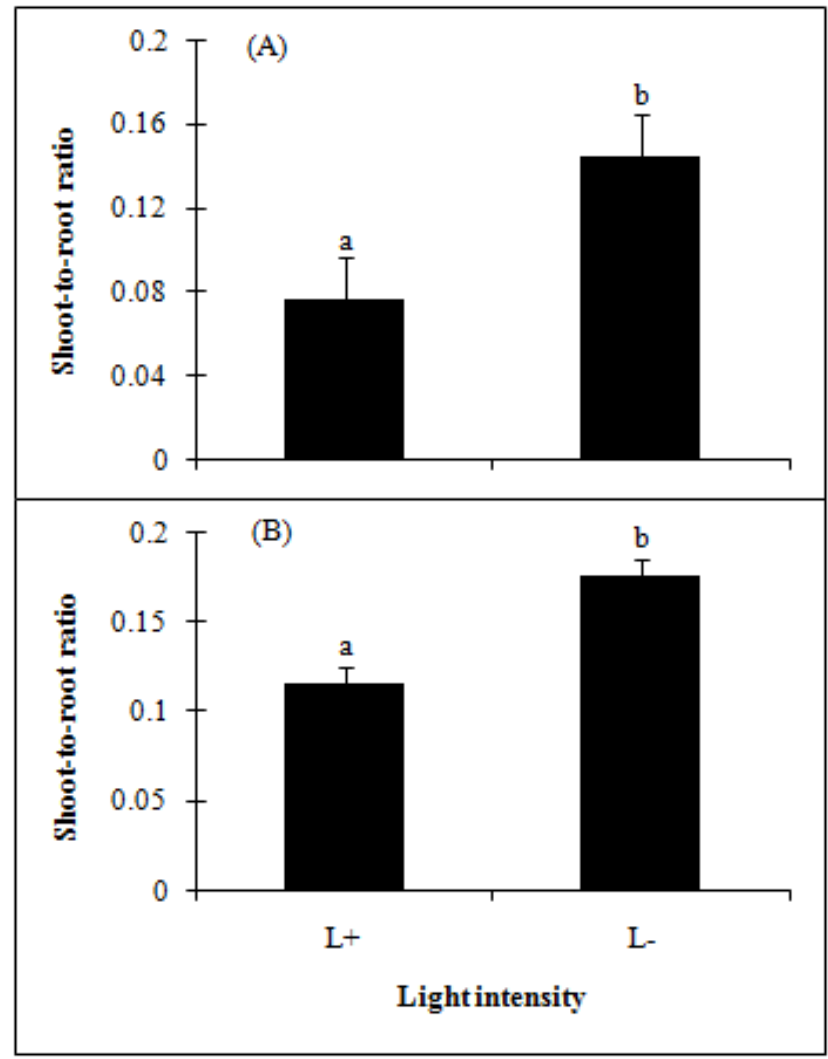

figure 6. Shoot-to-root ratio on cork oak (A) and zeen oak (B) seedlings according to light intensity (moderate $(\mathrm{L}+)$ versus low (L-) light intensity). Means \pm SE. Letters show significant differences between light levels.

\section{Discussion}

It has been reported since long that the first response to shade conditions is shoot elongation [38]. This was the reason for having, for both species, greater height growth under low than under moderate light intensity. Under shade conditions, seedlings are forced to grow towards light, to ensure their needs in this resource, and consequently to grow more in height [39]. It is important to note, however, that for cork oak increased height growth under low light intensity took place for well-watered seedlings, but nor for water stressed seedlings indicating that low water availability limited the seedlings' ability to cope with shading. This is because the water availability is the dominant stress factor. On the other hand, this means that water stress may aggravate growth of seedlings which are exposed to shading.

The increased height-to-diameter ratio observed for both oak species under low light level was also reported by Daas-Ghrib [8]. It attests for an unbalanced growth between height and basal diameter [40]. For cork oak, unbalanced growth is due to an increase in height and a decrease in diameter growth. For zeen oak, unbalanced growth was a function of height growth as there was no reduction in diameter growth, which reveals a progressive re-establishment of the plant growth balance.

Thanks to the primary growth decomposition, in GU, different growth characteristics can be underlined between seedlings grown under moderate and low light intensities. Seedlings grown under low light intensity expressed a significantly greater GU length for both established GU in cork oak, and for the first GU in zeen oak. Therefore, the greater height growth attributed to seedlings grown under low light level comes from the increase in GU length of the first GU for zeen oak, but also of the second GU for cork oak. Increased height growth in zeen oak only by increasing the first GU might indicate that after the establishment of this GU, seedlings ensured their needs in light. As previously reported, the stimulation of height growth under shade conditions stops when the plant reaches the demanded level of light [8]. As mentioned before, cork oak is described as less shade tolerant than zeen oak. For that reason perhaps there was a growth stimulation of both established GU for cork oak, which allows plant to profit the possible maximum from the available light, but only of the first GU for zeen oak. The increase in GU length accompanied by a decrease in the polycyclism rate observed in this study for cork oak confirms the results of Chaar et al [41] and Mechergui et al [37], who reported for the same species that GU length tends to be shorter as the polycyclism rate increases.

Although they had a greater height, seedlings grown under low light intensity did not express, in both oaks, an increase in their above-ground biomass compared to those grown under moderate light intensity. This indicates that this increase in height was not a result of an increase in dry matter production, but of a different 
allocation of assimilates which favored height growth and development of shoots in the distal part of the trees [40, 42]. Root biomass of trees has been shown to be adversely affected by water regime [43] and light [44]. In our study, root biomass growth was dependent on water regime for zeen oak, and on light level for cork oak. This is because deciduous species (i.e., zeen oak) are more shade-tolerant and water-demanding than evergreen species (i.e., cork oak) [45], which could explain also why diameter growth was independent of light intensity, and significantly reduced under water stress only for zeen oak. Burger et al. [46] reported that the reduction in root biomass could be the result of a reduced overall photosynthate pool (reflected by the reduction in total biomass production) and/or a repartition in photosynthate in favour the aerial part of plant causing a reduction in the root-to-shoot ratio. In this study, the reduction in root biomass of cork oak and zeen oak seedlings under low light intensity and water stress, respectively, is due to reduced overall photosynthate pool as well as to the unbalance in the distribution of photosynthate between the aerial and underground parts of plant, as both biomass production (total biomass) and shoot-to-root ratio were affected. Decreased allocation to roots in response to shade has been demonstrated in many studies [47, 48, 49,50]. However, increased investment in above-ground plant part under water stress, as suggested by the increased in the shoot-to-root ratio, is contradictory with what was established for along that under water deficit plant invests in root development $[51,52,53,54]$. In a general way, this morphological plasticity enables a plant to change its growth pattern when it encounters different stresses [55] and to enhance, consequently, its ability to face these stresses.

\section{Conclusion}

The study of cork oak and zeen oak seedlings' responses under changing light and water availability is of major interest, because the impact of the interaction between light and water availability can greatly help to understand regeneration success and niche differentiation in Mediterranean ecosystems. In this study, there was interaction between light and water availability for cork oak; thus, seedlings growing under no limiting water conditions were able to increase their height in response to low light intensity, while those growing under water stress were not. This suggests that cork oak can acclimate perfectly to shade conditions, when water conditions are not limiting. However, like most Mediterranean species, cork oak experiences an important drought during the summer season [56]; water stress may be, therefore, the bottleneck for recruitment of cork oak seedlings in shaded habitats. To avoid this situation, silvicultural treatments in cork oak stand under shaded conditions (i.e., forest gap, the reduction of undergrowth density or of tree density) in order to increase light penetration inside the population, and to favor consequently the regeneration of young plants, appear therefore necessary. Contrary to cork oak, shoot elongation in zeen oak was not significantly affected by an interaction between water and light, but by light alone. This demonstrates that water availability did not interfere with the response to light and that light affected the shoot elongation whatever the water regime applied. Contrary to cork oak, zeen oak did not lose its ability to acclimate to shade under water stress. It seems, thus, that zeen oak acclimated to shade conditions better than cork oak under water stress. Hence, the regeneration of zeen oak under shade and water stress would be more favored than that of cork oak. This implies that the ability of regenerated seedlings to respond to shade conditions under drought might influence patterns of forest distribution. The water stress applied in this study is a mild stress. Therefore, a higher intensity of water stress may increase the differences found in the range of applied water regimes. In addition, the responses reported at present may be linked to a threshold irradiance; hence, it is interesting to evaluate the combined application of light and water stress in a wider range of irradiance and water availability.

\section{Acknowledgements}

This research received financial support from the Superior Education Ministry and Scientific Research from Tunisia. The authors would like to thank the Instituto Nacional de Investigación y TecnologíaAgraria y Alimentaria (Madrid-Spain) for the assistance on this research. Special thanks are given to Enrique Garriga for helping in the setup of the experiment

\section{References}

[1]. MY Kwon, and S.Y.Woo, Plants' responses to drought and shade environments, AfricAfrican Journal of Biotechnology, 15(2), 2016, 29-31.

[2]. L Sack, and P.J. Grubb, The combined impacts of deep shade and drought on the growth and biomass allocation of shade-tolerant woody seedlings, Oecologia, 131, 2002, 175-185.

[3]. L Sack, P.J. Grubb, and T. Marañon, The functional morphology of seedlings tolerant of deep shade plus drought in three Mediterranean-climate forests of southern Spain, Plant Ecology, 168, 2003, 139-163.

[4]. B Hasnaoui, Chênaies du Nord de la Tunisie. Ecologie et Régénération, Thèse de doctorat d'Etat Es, Sciences Naturelles, Université de province-Aix-Marseille I, 1992.

[5]. L Roussel, Photologie forestière (Paris : Ed. Masson, 1972).

[6]. G Aussenac, and N. Bréda, Adapter la sylviculture aux contraintes hydriques, colloque des Journées Scientifiques et Techniques, 15 au 17 juin, INRA- Centre de Nancy, 2005. 
[7]. E.A. Pierson, R.N. Mack, and R.A. Black, The effect of shading on photosynthesis, growth and regrowth following defoliation for Bromus tectorum, Oecologia, 84,1990, 534-543.

[8]. C. Daas-Ghrib, Exigences comparées en lumière chez le chêne liège (Quercus suber) et le chêne zeen (Quercus canariensis) en forêt méditerranéenne. Cas de la Tunisie, Thèse de doctorat, Faculté des Sciences de Tunis, 2009.

[9]. A Devkota, and P. K. Jha, Effects of Different Light Levels on the Growth Traits and Yield of Centella asiatica, Middle-East Journal of Scientific Research, 5 (4), 2010, 226-230.

[10]. C.L. Ballaré, Keeping up with the neighbours phytochrome sensing and other signaling mechanisms, Trends in Plant Science, 4, 1999, 97-102.

[11]. H Gautier, P. Mech, P. Prusinkiewicz, and C. Varlet- Grancher, 3D Architectural modeling of aerial photomorphogenesis in White Clover (Trifolium repens L.) using L-systems, Annals of Botany, 85, 2000, 359-370.

[12]. R.E. Phares, Growth of red oak (Quercus rubra L.) seedlings in relation to light and nutrients, Ecology, 52, 1971, 669-672.

[13]. T.R. Crow, Reproductive mode and mechanisms for self-replacement of northern red oak (Quercus rubra)- a review, Forest Science, 34, 1988, 19-40.

[14]. J.D Hodges, and E.S. Gardiner, Ecology and physiology of oak regeneration, in D. L. Loftis and C. E. McGee, Oak Regeneration: Serious problems, practical recommendations (Symposium Proceedings), Gen. Tech. Rep. SE-84. Asheville, NC: U.S. Department of Agriculture, Forest Service, Southeastern Forest Experiment Station, 1993, 54-65

[15]. J.D. Johnson, R. Tognetti, M. Michelozzi, S. Pinzauto, G. Minota, and M. Borghetti, Ecophysiological responses of Fagus sylvatica seedlings to changing light conditions. II. The interaction of light environment and soil fertility on seedling physiology, Physiologia Plantarum, 101(1), 1997, 124-134.

[16]. M.M. Mendes, L.C. Gazarini, and M.L. Rodrigues, Acclimation of Myrtus communis to contrasting Mediterranean light environments effects on structure and chemical composition of foliage and plant water relations, Environmental and Experimental Botany, 45(2), 2001, 165-178.

[17]. A Zine El Abidine, Le dépérissement des forêts au Maroc : analyse des causes et stratégie de lutte, Science et changements planétaires / Sécheresse, 14 (4), 2003, 209-218.

[18]. [18] P.S. Nobel, Leaf anatomy and water use efficiency, in N. C. Turner and P.J. Kramer (Eds.), Adaptations of plants to water and High Temperature Stress (New York: Wiley, 1980) 43-55.

[19]. R. Zahner, Water deficits and growth of trees, in T. T. Kozlowski (Ed.), Water Deficits and Plant Growth (New York: Academic Press, 1968) 191-254.

[20]. T.T. Kozlowski, P.J. Kramer, and S. G. Pallardy, The physiological ecological of woody plants (San Diego, New York, Boston, London, Sydney, Tokyo et Toronto: Academic Press, 1991).

[21]. R Borchert, Phenology and ecophysiology of tropical trees: Erythrina Poeppigiana O.F. Cook, Ecology, 61(5), 1980, 1065-1074.

[22]. M. M. Larson, F.W. Whitmore, Moisture stress affects root regeneration and early growth of red oak seedlings, Forest Science, 16, $1970,495-498$

[23]. M. M. Larson, Effect of atmospheric humidity and zonal soil water stress on initial growth of planted northern red oak seedlings, Canadian Journal of Forest Research, 10, 1980, 549-554.

[24]. M Ksontini, Etude écophysiologique des réponses à la contrainte hydrique du chêne-liège (Ouercus suber) dans le Nord-Tunisie: Comparaison avec le chêne kermès (Q. coccifera) et le chêne-zeen (Q. faginea), Thèse de doctorat, Université Paris XI Val de Marne, 1996.

[25]. I.M. Perez-Ramos, L. Gómez-Aparicio, R.Villar, L.V. García, and T. Marañón, Seedling growth and morphology of three oak species along field resource gradients and seed mass variation: a seedling age-dependent response, Journal of Vegetation Science, 21(3), 2010, 419-437, doi:10.1111/j.1654-1103.2009.01165.x.

[26]. A Schoenenberger, and L. Salsac, Principales plantes caractéristiques des forêts de chêne-liège et de chêne zeen de Kroumirie et des Mogods (Tunisie : Revue de l'Institut National des Recherches Forestières, 1970).

[27]. J.L. Quero, R.Villar, T. Maranon, A. Murillo, R. Zamora, Plastic response to light and water in four Mediterranean Quercus species (Fagaceae), Revista Chilena De Historia Natural 81, 2008, 373-385.

[28]. INF (Inventaire National Forestier), Deuxième inventaire forestier et pastoral national. Inventaire des forêts par télédétection, 2010.

[29]. I Aranda, J. Puértolas, M. Pardos, and J. A. Pardos, Elevated atmospheric $\mathrm{CO}_{2}$ does not modify osmotic adjustment to light and drought in the Mediterranean oak Quercus suber L, Investigación Agraria: Sistemas y Recursos Forestales, 17(1), 2008, 0-0.

[30]. P.B. Rao, and S.P Singh, Effect of Shade and Moisture Gradients on Seedling Growth of Quercus leucotrichophora and Pinus roxburghii in Kumaun Himalaya, Proc. Indian natn. Sci. Acad. B 52 No. 5, 1986, 657-664.

[31]. M.G. Messina, and J.E. Duncan, Irrigation effects on growth and water use of Quercus virginiana (Mill.) on a Texas lignite surfacemined site, Agricultural Water Management, 24, 1993, 265-280.

[32]. G. G. Wang, and W.L. Bauerle, Effects of light intensity on the growth and energy balance of photosystem II electron transport in Quercus alba seedlings, Annals of Forest Science, 63, 2006, 111-118, doi: 10.1051/forest:2005103.

[33]. I Březina1, and L. Dobrovolný, Natural regeneration of sessile oak under different light conditions, Journal of Forest Science, 57 (8), 2011, 359-368.

[34]. P Champagnat, E. Payan, M. Champagnat, P. Barnola, S. Lavarenne, and C. Bertholon, La croissance rythmique de jeunes chênes pédonculés cultivés en conditions contrôlées et uniformes, in Comptes rendus du Colloque International sur l'Arbre, Naturalia Monspeliensa, $n^{\circ}$ hors série, 1986, 303-337.

[35]. R Harmer, Relation of shoot growth phases in seedling oak to development of the tap root, lateral roots and fine root tips, New Phytologist, 115, 1990, 23-27.

[36]. T. Mechergui, B. Hasnaoui, M. Pardos, and N. Boussaidi, First-year effects of tree shelters and mulching on survival and growth of zeen oak (Quercus canariensis Lamk) seedlings planted in North-Western Tunisia, Revue d'Ecologie (La Terre et la Vie), 67, 2012, 3-18.

[37]. T. Mechergui, M. Pardos, P., N. Boussaidi, B. Hasnaoui, and D. F. Jacobs, Development of cork oak (Quercus suber L.) seedlings in response to tree shelters and mulching in northwestern Tunisia, Journal of Forestry Research, 24 (2), 2013, $193-204$.

[38]. H Smith, Sensing the light environment: the functions of the phytochrome family, in R. E. Kendrick, and H. H. M. Kronenberg, (Eds.), Photomorphogenesis in plants (Dordrecht: Kluwer Academic Publishers, 1994) 377-416.

[39]. D.F. Jacobs, and K. Steinbeck, Tree Shelters Improve the Survival and Growth of Planted Engelmann Spruce Seedlings in Southwestern Colorado, WJAF, 16(3), 2001, 114-120.

[40]. T Mechergui, Régénération artificielle du chêne-liège (Quercus suber L.) et du chêne-zéen (Quercus canariensis Willd.): impacts du paillage et des abris-serres sur l'installation, la croissance et le développement architectural des plants, Thèse de doctorat, Faculté des Sciences de Bizerte, 2016. 
[41]. H Chaar, T. Mechergui, A. Khouaja, and H. Abid, Effects of tree shelters and polyethylene mulch sheets on survival and growth of cork oak (Quercussuber L.) seedlings planted in North-western Tunisia, Forest Ecology and Management, 256, 2008, 722-731.

[42]. F Famiani, P. Proietti, M. Micheli, M. Boco, and A. Standardi, Effects of tree shelters on young olive (Olea europaea) tree growth and physiology, New Zealand Journal of Crop and Horticultural Science, 35, 2007, 303-312.

[43]. A. Fabião, M. Madeira, E. Steen, T. Kätterer, C. Ribeiro, C. Araújo, Development of root biomass in a Eucalyptus globulus plantation under different water and nutrient regimes, Plant and Soil, 168-169, 1995, 215-223.

[44]. M.B. Dias-Filho, Physiological responses of Vismia guianensis to contrasting light environments, Revista Brasileira de Fisiologia Vegetal, 7(1), 1995, 35-40.

[45]. J.L Quero, R. Villar, T. Marañón, and R. Zamora, Interactions of drought and shade effects on seedlings of four Quercus species: physiological and structural leaf responses, New Phytologist, 170, 2006, 819-834, doi: 10.1111/j.1469-8137.2006.01713.x.

[46]. D.W. Burger, G.W. Forister, and R. Gross, Short and long-term effects of treeshelters on the root and stem growth of ornamental trees, Journal of Arboriculture, 23, 1997, 49-56.

[47]. W.J. Corré, Growth and morphogenesis in sun and shade plants. I. The influence of light intensity, Acta Botanica Neerlandica, 32, 1983, 49-62.

[48]. M.P. Dale, and D.R. Causton, The ecophysiology of Veronica chamaedrys, V. montana and V. officinalis. II. The interaction of irradiance and water regime, Journal of Ecology, 80, 1992, 493-504.

[49]. J Schmitt, and R.D. Wulff, Light spectral quality, phytochrome and plant competition, Trends in Ecology and Evolution, 8, 1993, 47-51.

[50]. A.J. Van Hinsberg, and P.H.Van Tienderen, Variation in growth form in relation to spectral light quality (red/far-red ratio) in Plantago lanceolata L.in sun and shade populations, Oecologia, 111, 1997, 452-459.

[51]. J. S. Amthor, and K. J. Mccree, Carbon balance of stressed plants: A conceptual model for integrating research results, in R.G. Alscher, Cumming, J.R. (Eds.), Stress Responses in Plants: Adaptation and Acclimation Mechanisms (New York: Wiley-Liss, Inc, 1990) $1-15$.

[52]. [52] T.E. Kolb, T.W Bowersox, and L.H. McCormick, Influences of light intensity on weed-induced stresses of tree seedlings, Canadian Journal of Forest Research, 20, 1990, 503-507.

[53]. T. E. Kolb, and K.C. Steiner, Growth and biomass partitioning of northern red oak and yellow-poplar seedlings: effects of shading and grass root competition, Forest Science, 36, 1992, 34-44.

[54]. P. D. Hare, W. A. Cress, and J. Vanstaden, The involvement of cytokinins in plant responses to environmental stress, Plant Growth Regulation, 23, 1997, 79-103.

[55]. W.H. Guo, B. LI, X.S. Zhang, and R.Q. Wang, Architectural plasticity and growth responses of Hippophae rhamnoides and Caragana intermedia seedlings to simulated water stress, Journal of Arid Environments, 69, 2007, 385-399.

[56]. M.D. Jiménez, M. Pardos, J. Puértolas, L.A. Kleczkowski, and J.A. Pardos, Deep shade alters the acclimation response to moderate water stress in Quercus suber L., Forestry, 82(3), 2009, doi:10.1093/forestry/cpp008. 